\title{
ERRATUM
}

\section{Erratum to: Non-adherence to antibiotic therapy in patients visiting community pharmacies}

\author{
Milene Fernandes • Andreia Leite - Maria Basto • \\ Miguel Araújo Nobre $\cdot$ Nuno Vieira $\cdot$ \\ Rui Fernandes $\cdot$ Paulo Nogueira $\cdot$ Paulo Jorge Nicola
}

Published online: 1 December 2013

(C) Koninklijke Nederlandse Maatschappij ter bevordering der Pharmacie 2013

\section{Erratum to: Int J Clin Pharm}

\section{DOI 10.1007/s11096-013-9850-4}

Unfortunately, one of the author's names was published incorrectly in the original publication. The correct name should read Paulo Jorge Nicola.

The online version of the original article can be found under doi:10.1007/s11096-013-9850-4.

M. Fernandes $(\bowtie) \cdot$ A. Leite $\cdot$ M. Basto - M. A. Nobre .

R. Fernandes $\cdot$ P. Nogueira $\cdot$ P. J. Nicola

Faculty of Medicine, Institute of Preventive Medicine,

University of Lisbon, Av. Prof. Egas Moniz - Ed. Egas Moniz,

1649-028 Lisbon, Portugal

e-mail: mccf@fm.ul.pt

M. Basto

Medical Department, RottapharmlMadaus, Lisbon, Portugal

N. Vieira

Internal Medicine Department, Centro Hospitalar do

Barlavento Algarvio, Portimão, Portugal

P. Nogueira

General-Directorate of Health (DGS), Lisbon, Portugal 